\title{
Understanding Review of Economic Loss Due to Government Policy Respond to the COVID-19 Disruption in Indonesia
}

\author{
Muhammad Sholahuddin \\ Universitas Muhammadiyah Surakarta, Indonesia \\ Corresponding author email: muhammad.sholahuddin@ums.ac.id \\ Sardjana Orba Manullang \\ Universitas Krisnadwipayana, Indonesia \\ Email: somanullang@unkris.ac.id \\ Dyana Sari \\ Universitas Tribhuwana Tunggadewi Malang, Indonesia \\ Email: dyana.unitri.online@gmail.com
}

\begin{abstract}
The emergence of the Coronavirus (COVID-19) pandemic followed by its aftermath has left a disaster for various lives and business activities. The impact of COVID-19 on the economy is a consequence of the national policies of each country in reducing the number of suspected victims of the COVID-19 pandemic. This paper aimed to understand the scenario of economic disruption in Indonesia due to a pandemic, which includes various economic sectors, including the weakening of the money cycle, increasing unemployment, supply of goods, changes in consumer behavior, scarcity, economic growth, and policies, stability. In collecting data, this study first mapped the theoretical impact of the national economy from the emergence of a pandemic. Next, we reviewed other evidence relevant to mapping to understand the causes and how economic impacts occur. Finally, we get an understanding of how economic disruption is, the impact of COVID-19 and an explanation of the disruption caused by government policies to combat the spread of COVID-19. These findings are scientifically valid and reliable because they have answered research questions in accordance with the plan of this study.
\end{abstract}

Keywords---coronavirus 2019, economic impacts, Indonesia, understanding economics.

\section{Introduction}

Since COVID-19 has become an international issue, the government has immediately focused its attention on the public health sector, producing several new policies that are rather sudden, such as the application of physical distancing, restrictions on public activities, which can prevent the transmission of the Coronavirus (Almuttaqi, 2020; Harirah, MS \& Rizaldi, 2020; Putra et al., 2020). Without realizing it, limiting the masses and social distancing has robbed people of daily mobility needs, hampered the interaction of the working community, which has led to a national economic recession as experienced by several countries that have participated in fighting the spread of the virus. Economic decline or loss can be understood as the pandemic's spread (Tirachini \& Cats, 2020).

What happened above did not appear to be too bad in just a few months, as the development of new cases continued to increase and spread not only in major urban centers in Java Island where the first cases were confirmed but also to areas throughout the province (WHO, 2020). Simultaneously, various policies were suddenly rolled out, such as closing markets, places of worship, universities, and all schools while paying attention to disease outbreaks. The government's initial estimates of the development trend of COVID-19 in several countries were effective in controlling and not sacrificing large amounts of state funds, such as the control strategy through social distancing, which was implemented not long after. The findings of Susilawati et al. (2020) prove that the current economic 
conditions are more than just the victory of COVID-19 itself, but more on the impact and risk of decline and loss of the national economy the component economy has skyrocketed considerably. So that many predict the Indonesian economy in the future is not easy to predict. It stands to reason that the consequences of the crisis have never occurred in this nation's history.

To control this uncharted epidemic, Gunawan (2020) proposes a national strategy to deal with the impact of the Coronavirus, such as the impact of economic hardship, by using structured controls by each country's governments. A consolidated national economic condition will ease some difficulties related to natural conditions and provide hope with the downward trend in new cases due to COVID-19 control measures. An important question that needs to be answered is to look at the causes of disruption and recovery. The national economy will soon recover to its original state with the expected growth trend before the emergence of COVID-19 or will continue to experience instability and economic losses due to the pandemic crisis. This policy becomes a dilemma as the country prepares to combat the spread of the Coronavirus with various approaches. The only way that has proven effective is to impose largescale social restrictions that sometimes do not work well in the field. What applies in their home country when WHO ensures the Coronavirus source must be a reference for Indonesia. Seeing the reality in many countries in Europe, policies such as lockdown have not worked. Likewise, in the US, which continues to be constrained by studies to ascertain the effectiveness of these large-scale limiting policies, it has created uncertainty about these policies (Ray \& Subramanian, 2020). Seeing the development of new cases, the government will be increasingly in a dilemma. Measures to limit society's movement must be stricter and longer for their impact to bear fruit so that all these policies contribute to a massive halt of economic and business activity.

Observing Indonesia's economic condition after the corona outbreak, data from various world meter sites until September 2020, positive Coronavirus cases globally reached 28 million, the cure rate was 20 million, and deaths at nearly one million. The highest number of sufferers is in Spain, Italy, England, and France. Meanwhile, the United States, Italy, Britain, Spain, and France had the highest number of deaths (Baldwin, 2020; Rodrik, 1996). Although the patients who recovered were more than those who died, the trend in sufferers and the death did not decrease (Loayza \& Pennings, 2020). Likewise, in Indonesia today, the domestic economy prospects still look bleak because the development of the number of Covid-19 cases has made politicians as national policymakers carried away by the latest developments so that the market is getting weaker. What missed in recent months is not part of the economic loss count? It estimated that a national survey stating the loss of their livelihoods in Indonesia would reach 11 million by 2020 .

Even though the data above cannot be trusted because it is not time to draw precise conclusions, however, this prediction is enough to make doubts for many parties to overly high factors that are not yet known to the broad community in the country: For example, how the Coronavirus spreads is not fully understood by changing policies. The sometimes ineffective medical and scientific roles of ensuring the continuation of Covid-19 patients' fate are still not understood by the public and government. On that basis, examples of the infectious virus's state and the proper immune solution are still confusing, especially if studies and experiments are just so limited. The business actor and policymakers' response is always inappropriate, constantly delayed, and wrong policies and implementation. All this has resulted in an increasing reaction from the business community and the public.

Perhaps one way of ensuring any government action is to follow scientists' and practitioners' advice when there is uncertainty. If this issue is not the case, then it is believed that all policies will lead to wrong estimates and inevitably lead to errors and fatal impacts. However, it is legitimate to avoid optional scenarios that might be useful for any government decision-making. Understanding the economic losses due to the disruption of COVID-19 requires an understanding of the disruption scenarios that will already occur. In this case, the government, as a policymaker, must understand the scarcity that needs attention.

The reason is that the economic disruption in 2020 will be pretty massive. It is also not only for the Indonesian government but also for other countries in the Asian region. How could it not be? Hopes for improving the economy this year after the first phase of the business agreement between the United States and China, which temporarily halted the trade war between the two countries, seemed to sink, and new uncertainties emerged due to the emergence of the coronavirus outbreak in many countries. Understand better; the following figure is the Indonesian economic projection.

\section{Methods}

This study aimed to understand the scenario of economic disruption in Indonesia after the COVID-19 pandemic, which includes various sectors of the business economy, such as weakening money circulation, increasing unemployment, disrupted supply of goods, unusual consumer behavior, scarcity of goods and services, economic 
growth and policies. Data collection, this study first identified and mapped the theoretical economic impact of the emergence of a pandemic until entering the 7th month (McCusker \& Gunaydin, 2015; O'Connor, 2013). Furthermore, we have reviewed some relevant evidence and updated it to map the latest actual conditions regarding national economic developments currently being affected by the COVID-19 outbreak. We conducted this review to understand the causes and how economic impact occurs. Finally, we can conclude an understanding of how Indonesia's economic disruption is affected by COVID-19 and an in-depth explanation of the disruption due to various government policies to slow the spread of COVID-19. Therefore, we firmly believe that these findings are scientifically valid and reliable because of the evidence that has answered the research questions according to plan (Drost, 2011).

\section{Result and Discussion}

The four simulations of the impact of COVID-19 disruption on Indonesia's poverty trends divide into three channels based on three conditions: low, medium, and high. In the light category, the economy grew by $4.2 \%$. The number of poverty will increase from $9.2 \%$ (September 2019) to $9.7 \%$ by the end of 2020 - meaning that approximately 1.3 million people as categorized as low. Meanwhile, in the moderate category, the economy will increase by $2.1 \%$, but the number of poverty people will increase by $11.4 \%$, meaning that 6 million people are suddenly poor. In a severe path, the national economy will advance by $1 \%$, and the poverty trend will skyrocket to $12.4 \%$, which means that 8.5 million people will become poor immediately.

\section{The weakening of the money cycle}

Weak money rotation results in purchases according to the demand for goods and services. This causes the circulation of money to decrease and is followed by a decrease in prices which causes inflation. As a result of weaker money circulation, one region's money and the country depreciate compared to the value of money in other regions. Because if a small business is the source of economic life in Indonesia. So with a weak money cycle, businesses are unable to create new productive jobs and are unable to encourage business innovation and competitiveness within the country. A new report by Hung \& Thompson (2016) shows that money turns can contribute 44 percent of economic activity in a region because money supply and class power are closely related to inflation.

The growth balance of savings and loans in Indonesia has decreased drastically in the past ten years since February 2020. It was a declining condition. It was caused by the COVID-19 pandemic reducing the credit capacity in almost all business activities in all regions (Altig et al., 2020; Krusell et al., 2002). The current banking condition has recorded a credit growth of 5.93 percent since March this year. This trend is the lowest starting in 2010. One of the sources of data on the circulation of money in Indonesia is from Bank Indonesia, where it mentioned the circulation of money in the form of currency during festive periods such as Eid 2019, which reached IDR.192 trillion, an increase of $13.5 \%$ compared to the similar period in 2018, which reached IDR. 191.3 trillion.

However, in Eid 2020 celebration, it has decreased significantly by IDR 158 trillion or $17.7 \%$. According to Loayza \& Pennings (2020), this decline can come from the government macroeconomic policy during COVID-19 in some developing countries. This decline is the systematic impact of the Covid-19 pandemic. However, if we look at the current reality, the amount of this decline can be even more significant. The indicator is that the national economic growth in the first quarter fell to $2.97 \%$. Another source also explained five reasons for the decline in money during this year's Eid. First, the head of community income has decreased due to national restriction policies such as social and physical distancing and large-scale federal social restrictions where more people spend time at home, preferably outside for productive activities.

\section{Increasing Unemployment}

The coronavirus pandemic (COVID-19) has caused unemployment rates in many countries around the world to soar. Many economic activities have stagnated due to social restrictions to suppress the spread of the virus. The findings of Kimura (2020), which says that the government's policy response to the pandemic (COVID-19) towards a decrease in regional cooperation and global production networks have been improving so far, has also caused more to stop working, especially domestically. The number of unemployed people in Indonesia also increased by 3.7 million people due to the pandemic. Today's unemployment rate is increasing, around 3.7 million, as the national development agency report. 
It is a relatively significant increase since the pandemic emerging in Indonesia. The increase in the unemployment rate was one of the government's considerations to increase the fiscal deficit to 5.2 percent from the previous 4.17 percent in 2020 . With the increase in the deficit, the government has an additional expenditure budget to drive productive sectors. The government hopes that there will be no further increase in both the unemployment rate and the number of poor people next year if the development of COVID-19 shifts to a low number of new cases. Besides, Chetty et al. (2011; Ihrig \& Moe, 2004) also argue that Covid-19 and each country's ability to make policies to stabilize expenditure and employment. It is a new real-time economic tracking strategy based on private-sector data in individual countries.

Based on Zubaidi et al. (2020) report, the high number of unemployed in the country is caused by low quality and access to education, lack of fields and opportunities for work, human resources' inability to compete, and lack of skills and insights. However, since the news of the spread of Covid-19, that number has jumped Mardiyah \& Nurwati (2020) stated that there were 84,926 companies, while the number of workers or laborers amounted to 1,546 million unemployed due to the occurrence of COVID-19. It has had a significant impact on the lives of the world's population. This has become a problem of the World Health organization because it is closely related to the level of health of the population of concern internationally to coordinate international responses to disease and other life difficulties.

\section{Goods supply drop}

One of the losses of COVID-19 is that the supply of goods and logistics is also severely affected by the current outbreak. So they are urged to be more aggressive in working on various supporting sectors so that there is no balance between the demand and supply of necessities in several regions in Indonesia. According to Fernandes (2020), the economic impact of COVID-19 on the world economy is very pronounced. Among other things, the supply and circulation of staple foods and other logistics hampered. Since the outbreak of the coronavirus or Covid19, logistics players faced with unequal policies between regions. Efforts to overcome this problem, each party's concern in the region to protect their area from virus infection is that large-scale restrictions in each region have disrupted the smooth flow of goods or logistics, especially the distribution of necessities. Ivanov (2020) predicts that the pandemic's impact on global.

\section{Consumer change behavior}

Laato et al. (2020) confirmed that buyers' behavior of goods and services was unusual in the early stages of the COVID-19 pandemic. The most fundamental change is in demand for staple goods and medicines and the way they are purchased, from what was usually to the market and the remote order method. As a consequence of consumer behavior changes during the coronavirus (COVID-19) pandemic, problems arose with the poor circulation of money and income for entrepreneurs.

On the other hand, we also find differences in consumption behavior, lifestyle, and spending priorities that customers have changed over the last few months and what they plan to continue under the new normal. In terms of media, the behavior has also changed, which is usually rarely watched and online, now television viewers have returned to the habit of watching films, series, news, information, and entertainment. The most obvious is the use of entertainment channels and social trends through media platforms. Baker et al. (2020) examine how household spending responds to the epidemic. They found that spending on household consumption and entertainment during the COVID-19 pandemic also increased than usual. It has had an impact on the decline of the national economy.

Consumers have prioritized the most basic needs, hygiene, hygiene, and necessities products soared, while the non-essential category fell. The factors that influence brand decisions also change as buying trends accelerate in the local market. Digital commerce is also rising as new consumers migrate online to shop for groceries, and an increase likely to continue after the Covid-19 outbreak. It also shows the costumer's way of thinking between personal and community concerns. The core change also comes to both the economy and health issues.

\section{Scarcity in essential items}

The COVID-19 also has an impact on rising prices and the scarcity of several goods in Indonesia. Since the news of the entry of corona in Indonesia, it made people panic. Some items were bought up by residents so that some items became rare and hard to find. Not only that but the prices of some goods have also become more expensive. Some items have started to be face masks since the coronavirus broke out in China. At that time, China needed many 
masks and asked Indonesia to export masks to their country so that masks in Indonesia were scarce, and the price was even higher. So since the coronavirus entered Indonesia, the selling price of masks has reached 15 times that. The price for this type of N95 mask can reach IDR 2 million per box. It happens because the stock of masks has decreased and cannot meet consumer needs, likewise with the components of essential goods and other services.

\section{Economic growth and policies}

Indonesia has been hit quite hard by the spread of the Coronavirus. Not only human health but this Coronavirus is also disrupting economic health around the world. Many studies estimate that Indonesia's economic growth in the worst-case scenario could be minus 0.4 percent. Likewise, based on Bank Indonesia's assessment economic growth will decline to 2.3 percent; Even in a worse scenario, it could be negative 0.4 percent.

The current condition impacts the decline in household consumption, which estimates at 3.2 percent to 1.2 percent. This condition also resulted in a sharp decline in investment. Previously, the government was quite optimistic that investment would grow by six percent. However, with the current condition of COVID-19, investment is expected to fall to a level of one percent or, at worst, it could reach minus four percent.

This study intended to understand Indonesia's economic conditions based on the above evidence that has resulted in "economic losses," such as in the findings above. However, a significant determinant could be the extent to which the disruption caused by COVID-19 can damage the economic transaction sector at various levels of business. More importantly, ownership of capital by both businessmen and government is essential. For example, during the current recession, where there are many bad loans and unbalanced capital stock, automatic recovery becomes difficult (Taskinsoy, 2020).

Eventually, it will end up increasing unemployment; skilled labor becomes scarce, production decreases; finally, economic disruption becomes severe and structural, and prolonged if it takes a long time. It will be a breakdown of culture; this is hard to understand. Khan \& Naushad (2020) review the critical condition of COVID-2019 in Italy and its impact on several countries' economies. Economic shocks and disruptions can now come from within the country itself, which changes from time to time. Scenarios can be winding or complex.

Another scenario could occur with weakening new economic growth sectors such as startup businesses and other small businesses. From the following questions, can it be identified where the disturbance is due to the coronavirus to date? The disruption's intensity has been greatly influenced by the corona viral trend following a policy response followed by consumer behavior changes and business resilience in overcoming crises and difficulties related to the pandemic. However, McKibbin \& Fernando (2020) see the global macroeconomic impact of COVID-19 with several recovery scenarios may greatly help the government. So that if the Coronavirus trend determines the disruption, then economic losses will start from within the country if Indonesia is unable to innovate policies, especially the depletion of endowments. At this point, distractions build-up from within and are easy to understand. It is the government's dilemma in carrying out policies related to fighting to win the corona or stabilizing the national economy at home.

\section{Importance of research results}

Søreide et al. (2020) noted that the immediate and long-term impacts of the COVID-19 pandemic on the economy and the government services' delivery would continue. The conditions and consequences of national economic losses due to Covid-19 are essential for the government, business organizations, and other related groups with great concern about economic development in Indonesia. Those people understand this particular economic disruption through various mechanisms, and the government can take multiple approaches to cure structural damage and non-structural risks.

Therefore, this economic issue is so essential for many parties to acknowledge. Structural risks in the financial policy related to public health, with the typical health problems caused by Covid-19, have left pressure and disruption on the national economy and business, triggering high sentiment and hindering banking activities, especially the central bank as the controlling banking system in Indonesia. If the liquidation problem continues to be high, followed by shocks in the real economy sector, this could lead to economic collapse. Therefore, it is not the government's choice.

According to Hesse \& Rafferty (2020), if the relational state policy will disrupt, the impact reflections regions in the country's home economy will also be affected by COVID-19. Other scenarios can become problematic due to national fiscal policies, and the solutions may not be understood. The risk of disruption to the national economy and the real economic sector is closely related to the disruption of COVID-19 that continues over a long period. This trend will increase economic losses in all sectors that influence the downward trend in transaction behavior. So it is 
not easy to do push-ups. Meanwhile, if the economic disruption continues to impact the real sector economy, the stagnation of various business transactions, trade, and bank debt arrears will continue.

Besides, the condition of the COVID-19 disruption threatens the Indonesian economy and several countries, both developed and developing countries. Although various policies regarding impact recovery efforts are the primary response to financial risks and impacts, such cases are unlikely to be allowed to continue, such as the massive closure of the actual economic sector. In other words, it cannot spontaneously solve the liquidity problem in all sectors of the domestic economy.

\section{Future scenario directions}

The new Normal era is to start over. The world economy is in the transition from level to battle. Deliberate Indonesian government policy decisions are necessary. Decisions cannot control businesses, but business activities will ensure that they are ready to enter the new expected time.

The fight against the COVID-19 will continue. The battle with the pandemic will take time to anticipate by most of the other leaders in the world. All can hope that it will not be long before a highly effective vaccine or treatment can be developed and used to keep new cases to a minimum. The Indonesian government's struggle will be fierce and more economically challenging than most outside world leaders expect because Indonesia's situation is different: the consumer and worker community's trust.

Due to the risk of further outbreaks and government protocols, it is inconceivable to have a sustainable impact on its economy. The government scenario that focuses on health protocols and mass restrictions has not shown any significant positive impact. As a result, the micro economy, such as residents' income or employment, not showing interventions and policy responses will significantly affect national economic improvement conditions.

In the future, the government and other parties may prepare and anticipate this economic loss due to the COVID disruption is through another route that may be surprised if the anticipated funds and bank recapitalization reap pro and contra polemics between politicians and executives, which in turn, have implications for the policy products of the recovery strategy (McKibbin \& Fernando, 2020; Åhman, 2006). The cases of the economic crisis affected by Covid-19 are very diverse and complex. Damage and other losses can also be assessed from the real economy sector scenario, which sometimes weakens rapidly. The risk of this damage can be confirmed and spread throughout the region when the government takes the wrong approach.

During the first semi-lockdown phase at the start of the emergence of Covid-19, all major cities in Indonesia got a severe panic to anticipate the condition. With old social and physical policies, they can also deplete the capital stock, which will weaken public participation in industry and business, which disrupts national productivity and efficiency growth. Unlike financial disruption itself, it is not a pandemic impact. The prolonged policy of limiting community activities on a large scale can damage business transaction activities, and industrial activities will also color the new policymaking for national economic recovery (Muzakki, 2020; Cumming, 2007).

According to Donthu \& Gustafsson, (2020), there are several potential strategies to avoid prolonged economic losses in the future. The strategy must come from several policy studies on existing strategies due to the impact of COVID-19, which involves all critical components, namely medical practice, academics, business people, government, scientists, and components of society who are directly involved in policymaking. This strategy has shown its effectiveness in how many countries have been effective against COVID and its economic impacts. However, it is essential to understand that almost no distraction reduction scenario can describe an effective strategy for overcoming the above problems. Often things happen inevitably; attacks occurred in all major economic sectors to all corners of the region. Indeed, different countries, of course, have different ways and experiences of getting through the difficult times affected by COVID-19, which differ significantly from country to country for two reasons; financial structural reliability to handle risk.

On the other hand, policy products' medical ability and capacity to respond with innovative strategies beat challenges even though they have never experienced it. Now one can ask whether the Indonesian government can implement the latest strategies and innovations? Of course, with the government's lack of experience in handling conditions like this before, it would be impossible to do it. Will Indonesia overcome complex and seemingly unattractive challenges because it has to face the threat of life of medics due to COVID-19, which has also crippled the national economy? 


\section{Medical perspective scenario}

Le et al. (2020) describe the development landscape of the COVID-19 vaccine, such as Nat Rev Drug Discov 19, which will bring new nuances in handling pandemic risk accompanied by sound government policies. If the vaccine program is successful, this time, it will support national policies of public restriction, social distancing, and the COVID-19 protocol. Thus the vaccine program will succeed in the country's agenda in restoring the financial recession and even the world health crisis. To achieve this, Indonesia and the world need a very challenging time and hard work. If the vaccine program is not successful, then the government's path and focus may be suitable for the program to innovate all approaches in terms of financial support solutions towards health and the risk of COVID-19 itself. Innovative efforts such as mentioned above are relevant to all medical centers. For example, efforts to prevent and treat new cases may have proven successful in dealing with victims.

Lurie et al. (2020) have reviewed several approaches to developing a Covid-19 vaccine with the pandemic speed and existing treatment programs in several countries that must evaluate their superiority. The other side of the COVID-19 spectrum is various government innovations to facilitate the medical capacity to respond to demands for medical resources, such as re-skills and upgrading of medical professionals towards optimization of modern standards, re-evaluation of space used for care and treatment. Indeed, all scenarios for dealing with COVID-19 sufferers and improving the priority of treatment and medical care by prioritizing Covid-19 disruption so that it does not continue to interfere with losses to the national economy need to continue to experiment study on target studies.

\section{Conclusion}

The goal of this paper is to understand the scenario of Indonesia's economic disruption due to the COVID-19 pandemic, which impacts many economic sectors, including weakening of the currency exchange rate, increasing unemployment, disrupted the supply of goods, erratic consumer behavior, scarcity of goods and services, market growth, and changing policies and financial stability. After a series of data studies and evaluations, we finally got a unique understanding of how the national economic disruption occurred, the impact of COVID-19, and an explanation of the trouble resulting from government policies to slow the spread of COVID-19. We can dispute these findings, among others; economic growth and comparisons before and after Covid-19, weakening of the average currency, increased unemployment, disrupted the supply of goods, changes in market behavior, as well as a meaningful understanding of the discussion of various future economic recovery scenarios so that economic disruption due to COVID-19 can provide a financial experience and the interruption to multiple parties who may have an interest.

\section{Acknowledgments}

We authors would like to appreciative all colleagues and supervisors for the support and encouragement during the research and report this project with valuable feedback. Similarly our appreciation to the funding support from the ministry of technology and research. Without their support this paper would not be able to finish.

\section{References}

Almuttaqi, A. I. (2020). Kekacauan Respons terhadap COVID-19 di Indonesia. The Insigjts, 13.

Altig, D., Baker, S., Barrero, J. M., Bloom, N., Bunn, P., Chen, S., Davis, S. J., Leather, J., Meyer, B., \& Mihaylov, E. (2020). Economic Uncertainty before and during the COVID-19 Pandemic. Journal of Public Economics, 104274.

Åhman, M. (2006). Government policy and the development of electric vehicles in Japan. Energy Policy, 34(4), 433443. https://doi.org/10.1016/j.enpol.2004.06.011

Baker, S. R., Farrokhnia, R. A., Meyer, S., Pagel, M., \& Yannelis, C. (2020). How does household spending respond to an epidemic? Consumption during the 2020 covid-19 pandemic. National Bureau of Economic Research.

Baldwin, R. (2020, April 7). The Greater Trade Collapse of 2020: Learnings from the 2008-09 Great Trade Collapse. VoxEU.Org. https://voxeu.org/article/greater-trade-collapse-2020

Chetty, R., Friedman, J. N., Olsen, T., \& Pistaferri, L. (2011). Adjustment Costs, Firm Responses, and Micro vs. Macro Labor Supply Elasticities: Evidence from Danish Tax Records. The Quarterly Journal of Economics, 126(2), 749-804. https://doi.org/10.1093/qje/qjr013

Cumming, D. (2007). Government policy towards entrepreneurial finance: Innovation investment funds. Journal of Business Venturing, 22(2), 193-235. https://doi.org/10.1016/j.jbusvent.2005.12.002 
Donthu, N., \& Gustafsson, A. (2020). Effects of COVID-19 on business and research. Journal of Business Research, 117, 284-289. https://doi.org/10.1016/j.jbusres.2020.06.008

Drost, E. A. (2011). Validity and reliability in social science research. Education Research and Perspectives, 38(1), 105.

Fernandes, N. (2020). Economic effects of coronavirus outbreak (COVID-19) on the world economy. Available at SSRN 3557504.

Gunawan, C. I. (2020). Star OHappy: A New Civilization The Instant Mass Strategy to Overcome Corona virus, Fears, and Hunger in Various Countries. IRDH Book Publisher.

Harirah, MS, Z., \& Rizaldi, A. (2020). MERESPON NALAR KEBIJAKAN NEGARA DALAM MENANGANI PANDEMI COVID 19 DI INDONESIA. Jurnal Ekonomi Dan Kebijakan Publik Indonesia, 7(1), Article 1. https://doi.org/10.24815/ekapi.v7i1.17370

Hesse, M., \& Rafferty, M. (2020). Relational Cities Disrupted: Reflections on the Particular Geographies of COVID19 For Small But Global Urbanisation in Dublin, Ireland, and Luxembourg City, Luxembourg. Tijdschrift Voor Economische En Sociale Geografie, 111(3), 451-464. https://doi.org/10.1111/tesg.12432

Hung, H., \& Thompson, D. (2016). Money supply, class power, and inflation: Monetarism reassessed. American Sociological Review, 81(3), 447-466.

Ihrig, J., \& Moe, K. S. (2004). Lurking in the shadows: the informal sector and government policy. Journal of Development Economics, 73(2), 541-557. https://doi.org/10.1016/j.jdeveco.2003.04.004

Ivanov, D. (2020). Predicting the impacts of epidemic outbreaks on global supply chains: A simulation-based analysis on the coronavirus outbreak (COVID-19/SARS-CoV-2) case. Transportation Research Part E: Logistics and Transportation Review, 136, 101922.

Khan, N., \& Naushad, M. (2020). Effects of Corona Virus on the World Community (SSRN Scholarly Paper ID 3532001). Social Science Research Network. https://doi.org/10.2139/ssrn.3532001

Krusell, P., Kuruşçu, B., \& Smith Jr, A. A. (2002). Equilibrium welfare and government policy with quasi-geometric discounting. Journal of Economic Theory, 105(1), 42-72. https://doi.org/10.1006/jeth.2001.2888

Kimura, M. (2020). The Neutral Theory and Molecular Evolution. In M. Kimura (Ed.), My Thoughts on Biological Evolution (pp. 119-138). Springer. https://doi.org/10.1007/978-981-15-6165-8_8

Laato, S., Islam, A. N., Farooq, A., \& Dhir, A. (2020). Unusual purchasing behavior during the early stages of the COVID-19 pandemic: The stimulus-organism-response approach. Journal of Retailing and Consumer Services, 57, 102224.

Le, T. T., Andreadakis, Z., Kumar, A., Roman, R. G., Tollefsen, S., Saville, M., \& Mayhew, S. (2020). The COVID19 vaccine development landscape. Nat Rev Drug Discov, 19(5), 305-306.

Loayza, N. V., \& Pennings, S. (2020). Macroeconomic policy in the time of COVID-19: A primer for developing countries. World Bank.

Lurie, N., Saville, M., Hatchett, R., \& Halton, J. (2020). Developing Covid-19 vaccines at pandemic speed. New England Journal of Medicine, 382(21), 1969-1973.

Mardiyah, R. A., \& Nurwati, R. N. (2020). Dampak pandemi Covid-19 terhadap peningkatan angka pengangguran di Indonesia.

McCusker, K., \& Gunaydin, S. (2015). Research using qualitative, quantitative or mixed methods and choice based on the research. Perfusion, 30(7), 537-542.

McKibbin, W. J., \& Fernando, R. (2020). The global macroeconomic impacts of COVID-19: Seven scenarios. Brookings. https://www.brookings.edu/research/the-global-macroeconomic-impacts-of-covid-19-seven-scenarios/

Muzakki, F. (2020). The Global Political Economy Impact of Covid-19 and The Implication to Indonesia. Journal of Social Political Sciences, 1(2), 76-92.

O'Connor, A. (2013). A conceptual framework for entrepreneurship education policy: Meeting government and economic purposes. Journal of business venturing, 28(4), 546-563. https://doi.org/10.1016/j.jbusvent.2012.07.003

Putra, P., Liriwati, F. Y., Tahrim, T., Syafrudin, S., \& Aslan, A. (2020). The Students Learning from Home Experiences during Covid-19 School Closures Policy In Indonesia. Jurnal Iqra': Kajian Ilmu Pendidikan, 5(2), 30-42. https://doi.org/10.25217/ji.v5i2.1019

Rodrik, D. (1996). Coordination failures and government policy: A model with applications to East Asia and Eastern Europe. Journal of international economics, 40(1-2), 1-22. https://doi.org/10.1016/0022-1996(95)01386-5

Ray, D., \& Subramanian, S. (2020). India's Lockdown: An Interim Report (Working Paper No. 27282; Working Paper Series). National Bureau of Economic Research. https://doi.org/10.3386/w27282 
Søreide, K., Hallet, J., Matthews, J. B., Schnitzbauer, A. A., Line, P. D., Lai, P. B. S., Otero, J., Callegaro, D., Warner, S. G., Baxter, N. N., Teh, C. S. C., Ng-Kamstra, J., Meara, J. G., Hagander, L., \& Lorenzon, L. (2020). Immediate and long-term impact of the COVID-19 pandemic on delivery of surgical services. The British Journal of Surgery. https://doi.org/10.1002/bjs.11670

Susilawati, S., Falefi, R., \& Purwoko, A. (2020). Impact of COVID-19's Pandemic on the Economy of Indonesia. Budapest International Research and Critics Institute (BIRCI-Journal): Humanities and Social Sciences, 3(2), 1147-1156. https://doi.org/10.33258/birci.v3i2.954

Taskinsoy, J. (2020). COVID-19: Is the Great Outbreak a Sign of What the Future Has Stowed for the Human Race? Available at SSRN 3597434.

Tirachini, A., \& Cats, O. (2020). COVID-19 and public transportation: Current assessment, prospects, and research needs. Journal of Public Transportation, 22(1), 1.

WHO. (2020). Coronavirus Disease (COVID-19)_Events as they happen. https://www.who.int/emergencies/diseases/novel-coronavirus-2019/events-as-they-happen

Zubaidi, N., Pratama, R. G., \& Al-Fatih, S. (2020). Legal Perspective on Effectiveness of Pre-Work Cards for Indonesian People. BESTUUR, 8(1), 9-18. 